\title{
MulawarmanLawReview
}

\section{Interpretation Qualification Proof toward Humiliation Performer or Libel in Social Media}

\author{
Bayu Fermadi ${ }^{1}$, La Sina ${ }^{2}$, La Syarifudin ${ }^{3}$ \\ ${ }^{1}$ State Prosecutor, Samarinda, East Kalimantan. \\ E-mail: yasminefermady15@yahoo.com \\ ${ }^{2}$ Law Faculty of Mulawarman University, Indonesia \\ E-mail: lasina.fhunmul@gmail.com \\ ${ }^{3}$ Law Faculty of Mulawarman University, Indonesia \\ E-mail: la_syarifudin@yahoo.com
}

\begin{abstract}
Information openess is needed by society, the improvement of information technology sector, electronic media and globalization happens almost in all life sectors. Technology improvement which is marked with internet can be operated by using electronic media such as computer or handphone. Through internet, information exchange can be done fast, accurate and with cheap cost. Therefore internet can be media to ease someone to do type of criminal act which based on informaton technology (cybercrime) such as, criminal ac like libel, pornography, gamling, account breaking, and etcetera.

Related with libel via electronic media, as it is organized in Law Number 11 Year 2011 about Electronic Information and Transactions. Then this issue which is done and is also not missed from electronic media itself. The proof is issue which hold important role in investigation process in law. The provision about the criminal act method can be done toward person who is accused doing certain criminal act. This provision is organized in formal criminal law. ${ }^{1}$ Verification process becomes important because it will decides defendant fate. If proof result with proof of evidence which is determined with law does not enough proof the guilt which is accused to defendant, then defendant is freed from punishment. It is vice versa, if the defendant guilt can be proved with enough proof of evidence, then the defendant can be avowed guilty and will be punished according to valid law.
\end{abstract}

Keywords: Cybercrime; Electronic Information; Electronic Media; Libel.

Citation: Fermadi. B, La Sina, \& La Syarifudin. "Interpretation Qualification Proof toward Humiliation Performer or Libel in Social Media". Mulawarman Law Review 3, no. 1 (2018): 30-47

\section{INTRODUCTION}

Information technology holds important role nowdays or in future. Information technology is believed to bring big benefit and importance for the country. In globalization era nowdays technology which is very develop is internet technology.

\footnotetext{
1 Andi Hamzah, Hukum Acara Pidana dalam Teori dan Praktek, Ghalia Indonesia, Jakarta,
} (2004): 2 
Development and usage of technical device which can help all form of human activity in entertainment, education, trading, governance and communication sectors. It is common issue. Information technology improvement nowdays and its possiblity in future will not be missed from encouragement which is done by communication technology and computer technology developments, whereas computer technology and telecommunication is encouraged by micro electronic, material, and software technologies. Combination of communication and computer tehcnologies bring internet becomes backbone for information technology.

Information openness is needed by society, improvement in improvement of information technology, electronic media, and globalization happen in all life sectors. Technology improvement which is marekd by internet can be operated by using electronic media such as computer or handphone. Through internet, information exchange can be done fast, accurate and with cheap cost. Therefore, internet can be media which eases someone to do various criminal act based on information technology cybercrime) such as, criminal act of libel, pornography, gamling, account breaking, and etcetera. ${ }^{2}$

Utilization or technology misused is not only a form of main human activity but also activity method in every sector. Since it is approved the statement that human activity in various forms cause emergence and law application or the making of various standard to organize that activity, it looks clear that technology must be opened then it can be organized by the law.

Related with libel criminal act, Criminal Procedural Code terms it as general and particular libel. Particular lander in Penal Code of Indesia is libel which is organized outside of Chapter XVI in Criminal Procedural Code. ${ }^{3}$

Based on Article 310 section (1) Criminal Procedural Code, libel which can be crime must be done by "charging him with a certain fact, with the obvious intent" with purpose that accusation will be announced (known by many person). Act which is accused does not require an act which can be punished such as stealing, embezzlement, adultery and etcetera. Those acts are enough to be common act, which is humiliating act, for example to accuse someone to have affair. In this case, it is not act which can be punished, but it is humiliating enough if it is announced. That accusation must be done verbally, if it is done in writting (letter) or picture, then that libel is named "to offend by letter (written)", and it can be applied Article 310 section (2) on Criminal Procedural Code.

\footnotetext{
${ }^{2}$ Dikdik M. Arif Mansyur, CYBER LAW Aspek Hukum Teknologi Informasi, PT. Refika Aditama, Bandung, (2005) : 3

${ }^{3}$ Reydi Vridell Awawangi, Pencemaran Nama Baik dalam KUHP dan Menurut UU No. 11 Tahun 2008 tentang Informasi dan Transaksi Elektronik, Lex Crimen Vol. III/No. 4/ Ags-Nov/2014, (2014) : 113
} 
Related with libel crime through electronic media as it is organized in Act Number 11 Year 2008 about Informatio and Electronic Transaction, then proof issue which is done is not missed from electronic media usage itself. Proof holds important role in criminal act investigation process. Determination about proof method in criminal act can be done toward person who is suspected doing certain criminal act.

These provisions are organized in formal criminal act or Criminal Procedural Code. ${ }^{4}$ Proving process becomes important because it will determine defendant fate. If proving result with proof of evidence which is organized by law that is not enough to proof guilt which is accused to defendant, then defendant can be freed from law. It is vice versa, if the defendant guilt can be proved with enough proof of evidence, then the defendant can be avowed guilty and will be punished according to valid law. That issues formulation which will be delivered are (1) How is proving interpretation qualification toward libel in social media? (2) How is law construction toward libel criminal act if its reviewed from criminal law?

\section{METHOD}

This normative law writting method uses several research laws, as follows toward relevant law theories to answer problem which is lifted, conceptual in research that refers to law principles which can be found in law schoolars point of views or law doctrines and also constituion regulation which is related with highlighted law issues.

\section{DISCUSSION}

\section{Libel Criminal Act and Cyber Crime Type}

\section{Definition of Libel Criminal Act}

R. Soesilo explains what it means with "to libel" that is "to attack someone honor and libel". Someone who is attacked usually "Embarrassed". "Honor" which is attacked here not just about honor but also "libel", it is not "Honor" in sexual. According to R. Soesilo, libel in Criminal Procedural Code in Indonesia are, as follows: (1) Libel by verbal ("smaad"); (2) Libel by writting ("smaadschrift"); (3) Libel ("laster"); (4) Libel by act ("lasterlijke verdachtmaking").

Provisions about libel which is in Chapter XVI, Book ii of Criminal Procedural Codeh is still relevant. Libel or defamation literally can be meant as an act that causes libel and loss to someone's honor. The early development of libel organizing is known since 550 B.C on formulation "twelve tables" in Ancient Rome. But, this provision is often used as affirmation of otoritarian authority with cruel punishments. In Emperor Agustinus era

\footnotetext{
4 Andi Hamzah, Hukum Acara Pidana dalam Teori dan Praktek, Ghalia Indonesia, Jakarta,
} (2004): 2 
(63 B.C), special defamation court (it is often calld libelli famosi) keeps increasing significantly. It is inherited hereditary to several law system in other countries, including England in Common Law environment, and France as one of important country in Civil Law system. ${ }^{5}$

In Criminal Procedural Code, libel is termed as slender toward someone, it is in Chapter XVI, Book ii of Criminal Procedural Code in Article 310 section (1) and (2), Article 311 section (1) and Article 318 section (1) of Criminal Procedural Code which are mentioned, Pasal 310 KUHP : (a) The person who intentionally harms someone's honor or reputation by charging him with a certain fact, with the obvious intent to give publicity thereof, shall, being guilty of libel, be punished by a maximum imprisonment of nine months or a maximum fine of three hundred rupiahs; (b) If this takes place by means of writings or portraits disseminated, openly demonstrated or put up, the principal shall, being guilty of libel, be punished with a maximum imprisonment of one year and four months or a maximum fine of three hundred rupiahs. Elements from article 310 section (1), as follows :

a. Any person: Who is interpreted as individual as law subject.

b. Deliberate; to do act which against with law and criminal act.

c. To damage someone's or someone's name; to do act that can understimate someone's pride, status along with someone's dignity.

d. To accuse; to give an unclear truth statement that can cause prejudice toward other person.

e. To do an act with real intention; an act which is done based on conciousness and has an intention and purpose that want to be achieved.

Elements from article 310 section (2), as follows :

a. Any person; who is interpreted as individual as law subject.

b. Deliberate; to do an act which against with laws and crimincal act.

c. To damage someone's or someone's name; to do act that can understimate someone's pride, status along with someone's honor.

d. To accuse; to give an unclear truth statement that can cause prejudice toward other person.

e. To do an act with real intention; an act which is done based on conciousness and has an intention and purpose that want to be achieved.

5 https://issuu.com/tifafoundation/docs/menggugat_pasal-pasal_pencemaran_nama_baik/ 32 diakses pada tanggal 26 Juli 2017 pukul 12.18 Wita 
f. If this takes place by means of writings or portraits; it is done by indirect face to face with other person but it takes place by means of writings or portraits.

g. It is showed on public or posted: that accusation is not aimed directly toward other peole but it is posted in public places with purpose that all persons can know it.

Article 311 section (1) of Criminal Procedural Code "Any person who commits the crime of slander or libel in ease proof of the truth of the charged fact is permitted, shall, if he does not produce said proof and the charge has been made against his better judgment, being guilty of calumny, be punished by a maximum imprisonment of four years".

Elements from that Article, as follows:

a. Any person: Any person; who is interpreted as individual as law subject.

b. To do libel with writting; To do a libel to someone directly (face to face) or written.

c. It is allowed to prove; Any person who commits the crime of slander or libel in ease proof of the truth of the charged fact is permitted. Pasal 318 ayat (1) KUHP "Any person who with deliberate intent by some act falsely cast suspicion upon another person of having committed a punishable act, shall, being guilty of calumnous insinuation, be punished by a maximum imprisonment of four years".

Elements from that article, as follows:

a. Any person; who is interpreted as individual as law subject.

b. Deliberate; to do an act which against with laws and crimincal act.

c. To do an act; to do an act which is in law and has criminal law for someone who breaks it.

d. To cause other person to be fake defendant is an act that can be punished.

\section{Libel Criminal Law and Definition of Cyber Crime}

Oemar Seno Ajdi interpret libel as an act that attact someone's honor or name "aanranding of goede naam" which can be formed of written libel by accusing an issue, and simple libel who does not contain written libel that is done toward someon. ${ }^{6}$

Oemar Seno Adji in his book classified libel acts become 2 (two) forms, those are material and formal libels. ${ }^{7}$ Material libel which consist of a truth that includes

\footnotetext{
${ }^{6}$ Oemar Seno Adji, Perkembangan Delik Pers di Indonesia, Erlangga, Jakarta, (1990) : 36

${ }^{7}$ Ibid
} 
objective statement verbally or written, then it becomes factor which determine the content from statements which are used written or verbally. But there is a possiblity to prove that accusation is done for general interest. Whereas formal libel as someone who is concerned is stated. Form and method are defining factors, it possibles to prove truth from no accusation and it can be mentioned as that possibility is closed.

Act Number 11 Year 2008 about Electronic Information and Transactions can be mentioned as a law which orgsnize specifically about cyber crime. ${ }^{8}$ Therefore, to understand what it meant with cyber crime itself. Then it needs to be explained cyber crime definition, crime types, and regulations in Indonesia which can be related with cyber crime beside Act Number 11 Year 2008 about Electronic Information and Transactions.

Terminology cyber crime is defined as computer crime. About definition from computer crime itself, until now there is no same opinion from schoolars. Although in english, computer term usage is still not same. Several terms which are often to be used in computer criminal act are computer misuse, computer abuse, computer fraud, computer-related crime, computer-assisted crime, atau computer crime. ${ }^{9}$

Barda Nawawi Arief mentions the definition of cyber crime with criminal act which is identical with criminal act in cyber space. ${ }^{10}$ The British Law Commision uses computer fraud to interpret cyber crime, which meant as computer manipulation by any methods which is done with spite to get money, or other profit or it is meant to cause loss on other party. ${ }^{11}$

Eoghan Caseh in his book with title Digital Evidence and Computer Crime: Forensic Science, Computers, and the Internet writes that cyber crime is general term which is used by organizations in the world such as U.S. Departement of Justice (USDOJ) and Council of Europe to give definition widely toward crime which involves computer and network. $^{12}$

\footnotetext{
8 Penjelasan Umum Undang-Undang Nomor 11 Tahun 2008 tentang Informasi dan Transaksi Elektronik

${ }^{9}$ Widodo, Sistem Pemidanaan dalam Cyber Crime, Yogyakarta, Laksbang Mediatama, (2009): 23

${ }^{10}$ Barda Nawawi Arief, 2013, Kapita Selekta Hukum Pidana, cetakan ke-3, Bandung, PT. Citra Aditya Bakti, (2013): 201

11 Budi Suhariyanto, Tindak Pidana Teknologi Informasi (Cybercrime) Urgensi Pengaturan dan Celah Hukumnya, PT. Rajagrafindo Persada, Jakarta, (2013) : 11

12 Eoghan Casey, Digital Evidence and Computer Crime: Forensic Scince, Computers, and the Internet: Third Edition, Maryland, Elsevier, (2011): 37
} 


\section{Cyber Crime Type}

Cyber crime types can be explained as follows: ${ }^{13}$ Unauthorized Access to Computer System and Service/Internet Instrusion, Illegal Contents, Data Forgery, Cyber Sabotage and Extortion, Cyber Sabotage and Extortion, Offense Against Intellectual Property, Infringements of Privacy, Cracking/Hacking, Carding, Defacing, Phising/Indentity Theft, Spamming/Harassment Through E-Mails, Transmitting Malware.

Unauthorized Access to Computer System and Service/Internet Instrusion, This cyber crime type is crime where the act that against law in form of entering the computer network unofficially, without permission or without network owner knowing it. The example of this cyber crime tpe usually by accessing a websibe uses other person username;

Illegal Contents, This cyber crime is crime type where crime type where the act against the law by transmitting the data or spread the not true information about something, unethical, and it is considered to break law or disturb general interest. The example of this cyber crime is piracy data (distribution of pirated software).

Data Forgery, This cyber crime type is crime type where act against law is an act of forge the data which can give profit to suspect or other person by method that against the law. This crime usually in form of e-commerce documents forgery that are used to get information from the victim or to enter employee's salary more than the due.

Cyber Sabotage and Extortion, This cyber crime is type of crime where an act against the law by making disturbance, desecration or destruction toward data, computer program or computer network which are connected with internet. This crime is done by infiltrated a program that can cause desecrtion on data, computer program or computer network which are targeted.

Offense Against Intellectual Property, This crime type is crime where the act is against law which is intended toward Intellectual Property Rights who are owned by other party. For example such as image imitation illegally, data spreading is someone's trade secret and etcetera.

Infringements of Privacy, This cyber crime is type of crime where their act against law in form of missused or spreading of personal inforamation which is owned by someone that can cause loss toward that person on their material or non-material, for example such as credit card, ATM pin number, cripple or hidden illness and etcetera.

Cracking/Hacking, Cracking sometimes is considered as an act which is intended to do act against law, whereas hacking is considered as an act that is not surely as it is

13 Petrus Reinhard Golose, 2008, Seputar Kejahatan Hacking: Teori dan Studi Kasus, Dharmaputra, Jakarta, (2008) : 27 
intended to do act against law. It can not be mentioned as true, because basically what differs both terms just on the usage of its terms, whereas the act which is done can be mentioned as same. Therefore, it can be mentioned that between cracking and hacking cannot be differ in front of law, about if mens rea the suspect on that time is done just affect on the decision consideration but it does not affect the type of action.

Carding, This cyber of crime where the act against law in form of by using other person credit card without or approval with the result it will causes loss that person material or non-material. Carding can be called as trans-national crime. It is caused because of carding can be done by anyone as long as they have credit card number which can be misued and from everywhere as long as there are computer and internet.

Defacing, This cyber crime is type of crime where act against law in form of changing page of site/website the other party. In Indonesia this type of crime is ever happened on Ministry of Communication and Information Technology and Golkar Party, Indonesian Bank and General Election Commission sites. These crimes type are usually done with intention to get information from them who access that site, but sometimes it is done without any intention to do serious crime.

Phising/Indentity Theft, This cyber of crime where act against law in form of information theft about identity of a site. That information usually is obtained through defacing in a site. This crime type usually direct to site visitors who use online banking where information which is obtained from them are used to get money or to misuse credit card number from the victims.

Spamming/Harassment Through E-Mails, This cyber of crime where act against the law where the act against law in form of the sending information via e-mail where that information is not wanted by the receiver. Spam is often called as bulk email atau junk e-mail. This type of crime sometime is used to do fraud toward its receiver, for example the information giving which states that the receiver won something then they must send their account number or to send money to claim the prize.

Transmitting Malware, This cyber of crime where act against the law where the act against law in form of spreading the malware. Which is meant from that issue is a computer program that has function to find weakness from a computer software then through its weaknes, misused act like system destruction, spam or information theft. Malware itself consist of various type, there are known as: virus which is usually spread via file which is obtained from other computer; worm usually is spread via email; trojan horse; adware and browser hijacker which usually spread via sites in internet. As the information and technology development, scope of this crime did not just apply on computer, but it can also enter electronic communication device scope, such as handphone. Cyber-child Pornography, This cyber of crime where act against the law where the act against law in form of act to spread information with child pornography 
content. Although this type of crime can be include in illegal content type in pornography context, but this cirime should be differed. It because of this crime type cannot be illegalized such as pornography in certain countries. By using child as object, almost all country in the world prohibit the its spread because it is considered as child sexual abuse. And it is against law. Where child pornography in form of photos which show children who involve in sexual behavior and to produce that material by itself are prohibited by law as child sexual abuse in most countries.

Qualification of Verification Interpretation Toward Libel or Libel Suspects in Social Media

Verification of a criminal act is organized strictly in Criminal Procedural Code. This system organize a process and how the proof of evidence works, for the next it is done the adjustment with material act which is done by the defendat, in the end the conclusion about the defendent is guilty or not with accusation which is accused to them. About this Article 183 Criminal Procedural Code states that judge cannot put the sentence to someone, unless there are two legitimates proves, he believes that a criminal act truly happen and the defendant is guilty to do it.

Proof of evidence has the same power with verification and other proof of evidence, but judge does not relate with conformity truth which is realized by the indication, judge free to adjudicate and use it in verification effort. Beside, the indication as proof of evidence cannot stand-alone to prove defendant guild, because judge is still related with prove minimum limit according to Article 183 Criminal Procedural Code that judge cannot put sentence to someone unless at least there are two legitimate proves. In Criminal Act of Corruption, voice record based on tapping on investigation process can be considered as indications, because it can be categorized as information and/or electronic document which is expanded from letter proof of evidence to be indication for judge to prove a case.

There is no provision which organize electronic proof on general court verification surely becomes issue which is dealt with law enforcement officers nowdays. To use electronic proof on verification of public criminal court surely will cause pros and cons about what is include in electronic proof, what is requirenment for electronic proof until it is guaranteed its origin, and how is the power of electronic proof verification.

About electonic proof, the truth in Indonesia there are several acts which point to usage and confession toward electronic document as legitimate proof, for example by the recognized of online trading in stock exchange and microfilm organizer along with electronic device as company document storage media which is organized in Act Number 8 Year 1997 about Company Document. 
Company Document Law can be mentioned is early organized toward eletronic verification, because it gave possibility to company document which is given position as authentic written proof of evidence, to be secured in microfilm. Furthermore document is saved in that electronic form (paperless) then it can be made as legitimate proof of evidence if there dispute is happened in court of law. Therefore, it can be mentioned that the appearance of Company Document Law is starting point for electronic in form of electronic document is approved as proof of evidence that can be submitted to court of law. In Act Number 24 Year 2003 about Constitutional Court (even it is not in dispute resolving on coverage of civil law), which also insert regulation about procedural law, to determine in Article 36 section (1) about proof of evidences which can be used on verification in Constitutional Court meeting, as follows: (a) Documentary evidence; (b) Witness statements; (c) Expert statements; (d) Statements of the litigants; (e) Indications; dan (f) Other proof of evidence in the form of information uttered, transmitted, received or stored electronically by way of optical instruments or similar device.

In Act Number 30 Year 1999 about Arbitrase and Arbitration and Alternative Dispute Resolution as notification document through Article 8 section (1) which mention that, "In the event that a dispute arises, the Claimant shall inform the Respondent by registered letter, telegram, telex, fax, e-mail, or by courier that the conditions for arbitration to be entered into by the Claimant and Respondent are applicable".

More strictly about regulations toward this electronic evidence, that is organized through Act Number 11 Year 2008 about Electronic and Information Transaction, which specifically organizes about electronic evidence. In Article 5 of Act Number 11 Year 2008 about Electronic and Information Transaction, it is mentioned strictly that information and/or electronic document and/or its printed result are legitimate proof of evidences and has legitimate due. For more complete in Article 5 of Act Number 11 Year 2008 about Electronic and Information Transaction, it mentions that:

a. Electronic Information and/or Electronic Documents and/or the printouts thereof are valid legal evidence.;

b. Electronic Information and/or Electronic Documents and/or the printouts thereof as intended by paragraph (1) shall be the expansion of lawful means of proof in accordance with the Law of Procedure applicable in Indonesia;

c. Electronic Information and/or Electronic Documents shall be declared to be lawful if using Electronic Systems in accordance with provisions as governed by this Law;

d. Provisions on Electronic Information and/or Electronic Documents as intended by paragraph (1) shall not apply to: (a) Electronic Information and/or Electronic 
Documents and/or the printouts thereof are valid legal evidence; dan (b) certificates together with their papers that under Laws must be made in notary deed or deed made by land conveyances.

From what is discussed above, the conclusion that in general form from those electronic evidences are formed of Electronic Information and Electronic Document, beside there is witness investigation by using teleconferences. According to Article 1 section (3) of Electronic and Information Transaction which is meant Electronic Information is "Electronic Document is any Electronic Information that is created, forwarded, sent, received, or stored in analog, digital, electromagnetic, optical form, or the like, visible, displayable and/or audible via Computers or Electronic Systems, including but not limited to writings, sounds, images, maps, drafts, photographs or the like, letters, signs, figures, Access Codes, symbols or perforations having certain meaning or definition or understandable to persons qualified to understand them."

Limitation about Electronic Documen, as it is organized in section (14) of that article are "Every Computer and electronic, magnetic, optical data processing device, or a system that performs logic, arithmetic, and storage functions; visible, displayable and/or audible via Computers or Electronic Systems, including but not limited to writings, sounds, images, maps, drafts, photographs or the like, letters, signs, figures, Access Codes, symbols or perforations having certain meaning or definition or understandable to persons qualified to understand them."

Verification system aims to know how to put a verification result toward case which is investigated. Based on verification, verification system which is believed is expected can give certainty in form of result and verification power. Result and power from verification are expected to give conviction to judge to adjudicate whether defendant is guilty or not. In Criminal Procedural Code does not explain in detail about verification system by court of law in Indonesia. Explanation which is in Criminal Procedural Code mentions that judge cannot put sentence to someone, unless there are two legitimates proves, he believes that a criminal act truly happen and the defendant is guilty to do it.

For verification which is followed in Indonesia is using two proof of evidences, but for fast penal law investigation beside one proof of evidence, it is organized in Article 205 until Article 206 of Criminal Procedural Code. In Article 184 of Criminal Procuderal Code is explained that for fast civil law investigation enough to be proved by one proof of evidence and judge conviction.

Electronic evidence can be interpreted into type of material evidence are materials which are used to get right things to convince judge for the defendant guilt toward criminal act which is accused. Legitimate proof of evidence in Article 184 of Criminal Procedural Code, is interpretation approach which is done done judge to electronic 
evidence by entering it into form of letter or indication. Interpretation toward electronic evidence makes it very possible to be done, considering there is no approval of the existence of public civil law electronic evidence. Electronic evidence can be iterpreted into type proof of evidence type, material evidence is materials which are used to get right things to convince judge for the defendant guilt toward criminal act which is accused.

Law invention is the main activity from judge to implement law if concrete event is happened. In law interpretation, electronic evidence law into form of material evidence or proof of evidence or this indication uses extensive interpretation law method. Extensive interpretation is interpretation by extending words method that is in law. An event can be entered inside it. In extensive interpretation law method, judge will expand words which are in law, will be related with even which is happened.

Until now criminal law still refers to Law Number 8 Year 1981 about Criminal Procedural Code. In Article 184 of Criminal Procedural Code, the legitimate proof evidence on Indonesia criminal law are Witness statements, Expert statements, Indications and defendant statements. Nowdays Indonesia criminal law does not organize yet about electronic evidence which is presented in court of law will cause controversy about how is technical assessment toward that electronic evidence. There is no law that organizes electronic evidence technical assessment, judge is expected to determine technical assessment toward electronic evidence power.

In this public criminal law, the provisions about electronic evidence does not organized specifically in Criminal Procedural Code, judge must do law invention to prevent vacuum of norm. Jugde as law enforcement officer who investigate, adjudicate and decide the case cannot reject case which is submitted to them with incomplete or unclear law reason, judge can use argumentation method because Criminal Procedural Code does not yet organize specifically about electronic evidence provisions.

In research about electronic evidence legitimacy which is presented in court of law, judge refers to expert statements to consider and guarantee that electronic evidence legitimacy. Expert as persons who has special skill about issue which is needed to make clear a criminal case for investigation importance, to give their opinion to judge about legitimate or not the proof of evidence which is presented to that court of law. When expert states that proof of evidence is legitimate, judge can acknowledge that proof of evidence can be responsibled legally. 


\section{Law Construction Toward Slander Criminal Law or Libel is Referred from Criminal Law} Perspective

Libel literally is an act to make someone inferior or to fall someone's level in society. However, this term has many similarities with emotion or humiliation. Libel habitually is not good experience, because it reduces ego. Libel doen not require involving other person, it can be self conciousness, and it can be a method to erase improper proud. Libel toward other person is often to used, and is in form of common abuse or pressure.

Issue or condition which is communicated or published via internet can be mentioned as slander or libel if issue or condition to damage reputation or to bring material loss for victim side. Publication or communication about other party can be mentioned as libel, it is done by words or writting which is barefaced or in hidden form, but it contains connotations which damage someone's or an agency. To be categorized as slander or libel, then elements must be fulfilled: ${ }^{14}$ (a) There are issue or incorrect which is communicated via internet; (b) That issue or condition about one's self or an agency; (c) Issue or that condition is published toward other party; and; (d) That publication causes loss for someone to be object.

In Article 27 section 3 of Electronic Information and Transactions there are 2 (two) elements, as follows: First, Objective elements in this article are (a) Act, to distribute, to transmit, to make it accessible; (b) Against law, which is meant without right; and (c) The object is electronic information and/or electronic document which make slander and/or libel. Second, Subjective element in form of guilt, which is meant "deliberately". All third acts distribute, to transmit, and to make information accessible and/or electronic document which cannot be found its explanation in that Law from juridical or informatic technology. If we see from this context, then truly in Article 27 section (3) of this Electronic Information and Transactions Law is lex specialis fromm Criminal Procedural Code because from specialization in Criminal Procedural Code in internet.

To deal with slander criminal act via internet, police officer uses articles in Criminal Procedural Code is related with articles in Electronic Information and Transactions Law as lex specislis in slander/libel criminal law, Article 27 section (3) of Act Number 11 Year 2008 about Electronic Information and Transactions are stated that "Any Person who knowingly and without authority distributes and/or transmits and/or causes to be accessible Electronic Information and/or Electronic Records with contents ofaffronts and/or defamation."

14 Asri Sitompul, Hukum Internet Pengenalan Mengenai Masalah Hukum Cyber Space, Citra Adiyta Bakti, Bandung, (2001) : 75 
Criminal law provisions related with libel which is done via internet network that is organized n Article 45 section (1) of Law Number 11 Year 2008 about Electronic Information and Transactions which is mentioned that "Any Person who satisfies the elements as intended by Article 27 section (1), section (2), section (3), or section (4) shall be sentenced to imprisonment not exceeding 6 (six) years and/or a fine not exceeding Rp1,000,000,000 (one billion rupiah)."

To deal with slander criminal case via internet, police officer uses articles in Criminal Procedural Code is related with article in Law of Electronic Information and Transactions as lex specialis in libel/slander criminal law, in Article 27 section (3) of Act Number 11 Year 2008 about Electronic Information and Transactions are stated "Any Person who knowingly and without authority distributes and/or transmits and/or causes to be accessible Electronic Information and/or Electronic Records with contents of affronts and/or defamation."

Provisions of criminal law related with libel which is done via internet network is organized in Article 45 section (1) of Act Number 11 Year 2008 about Electronic Information and Transactions which is mentioned that "Any Person who satisfies the elements as intended by Article 27 section (1), section (2), section (3), or section (4) shall be sentenced to imprisonment not exceeding 6 (six) years and/or a fine not exceeding Rp1,000,000,000 (one billion rupiah)."

Libel basically is act which is considered as unfair form before it is stated in law because it broke politeness. Even more than that, Libel is considered to break religion norm if libel substance has slender substance. There are three important notes related criminal libels are: ${ }^{15}$

1) That criminal act is very subjective. It means, the assessment toward libel depends on person or party that their name is attacked. Because of that, libel is criminal act that only can be processed by police if there are complaints from person or party who feel their name is libelled.

2) Libel can be the spread of criminal acts. It means substance which contains libel is spread to public or it is done in public by the suspect

3) Person who do the libel by accuse something which is considered to attack someone's name or other party must be given chance to proof that accusation.

Act which is can be done by libel suspect in internet can be categorized as criminal act because they disturbed public order and there are party which experience loss from that libel via internet. Libel criminal act through internet can be categorized to cyber crime.

${ }^{15}$ Asri Sitompul, Ibid. (2001) : 67 
That criminal law was organized in Article 27 section (3) of Act Number 11 Year 2008 about Electronic Information and Transactions states that every person deliberate or without authority distributes and/or transmits and/or causes to be accessible Electronic Information and/or Electronic Records with contents ofaffronts and/or defamation. Element which contains in that article are:

1) Every Person, Every person is individual, whether Indonesian or foreigner.

2) Deliberately and without authority, Deliberately and without authority are acts which are done by criminal sucspect that is planned or intended and without knowingly from person who has authority.

3) To distribute and/or to transmit and/or to make it accessible, to distribute an/or to transmite and/or to make it accessible are acts which are done by criminal suspect to spread their criminal acts to be known by many persons.

4) Electronic information which has slander and/or libel, electronic information has slander and/or libel content is one or group of electronic data, includes but it does not limit on writings, sounds, images, maps, drafts, photographs, electronic mail, telegram, telecopy, or like, letter, signs, figures, Access Codes, symbols or perforations which is processed then inside it contains slander element or libel to someone.

Basic law which has potention can be used to tangle someone which is considered was doing libel there are Article 310 of Criminal Procedural Code and Article 27 section (3) Electronic Information and Transactions and Article 45 section (1) Electronic Information and Transactions, which are mentioned as follows: First, Article 310 of Criminal Procedural Code:

a) The person who intentionally harms someone's honor or reputation by charging him with a certain fact, with the obvious intent to give publicity thereof, shall, being guilty of libel, be punished by a maximum imprisonment of nine months or a maximum fine of three hundred rupiahs;

b) If this takes place by means of writings or portraits disseminated, openly demonstrated or put up, the principal shall, being guilty of libel, be punished with a maximum imprisonment of one year and four months or a maximum fine of three hundred rupiahs.

c) Nether slander nor libel shall exist as far as the principal obviously has acted in the general interest or for a neccesary defence.

Second, Any Person who knowingly and without authority distributes and/or transmits and/or causes to be accessible Electronic Information and/or Electronic Records with contents of affronts and/or defamation. 
Third, Article 45 section (1) Electronic Information and Transactions law mentions (1) of Any Person who satisfies the elements as intended by Article 27 section (1), section (2), section (3), or section (4) shall be sentenced to imprisonment not exceeding 6 (six) years and/or a fine not exceeding Rp1,000,000,000 (one billion rupiah). And special for mailing list, where the writting is loaded in electronic media (in this case is internet), then libel in a mailing list is including in libel via electronic information, it has criminal law which is organized in Article 45 section (1) of Electronic Information and Transactions Law.

The difference opinion between substance on Article 27 section (3) of Information and Electronic Transaction Law. There are opinions that are interpreted in Article 27 section (3) of Information and Electronic Transaction Law related with Article 310 of Criminal Procedural Code, where element "in front of public" also applies in electronic information spreading which contains slander and/or libel, for example electronic information which is spread via email is mentioned, it does not fulfill element in front of public because its characteristic is close inter individual.

Whereas, other opinion the element in front of public is used to spread electronic information because electronic information spread are: fast, has various strips (such as email, web, sms) and wider coverage, with the result electronic information which is spread via email does not require to be argued and related with element in front of public, and Information and Electronic Transaction Law reaach all kind of electronic information spread whether it is close (example via email), or open (example via website).

\section{CONCLUSION}

In general crime, provisions about electronic proof of evidence does not organized specifically in Criminal Procedural Code, judge must do law invention to prevent vacuum of norm. In assessment about electronic evience legitimacy which is presented in court of law, judge refers to expert statements to consider and guarantee that electronic evidence legitimacy. Expert statements to consider and guarantee that electronic evidence legitimacy.

Slander or libel punishment which is on Information and Electronic Transaction Law in Article 45 section (1) is mentioned that maximum imprisonment of 6 (six) years and/or maximum fine of one billion rupiah, this punishment is surely bigger than punishment in Criminal Procedural Code. It based on consideration that slander or libe via electronic system has bigger, massive, and destructive impacts tan libel conventionally. As the result to use slander or libel article in Information and Electronic Transaction Law which is suspected to do slander or libel because Information and Electronic 
Transaction Law toward someone who is suspected to do slander or libel because Information and Electronic Transaction Law believes maximum imprisonment.

\section{SUGGESTIONS}

To do recodification or reunite libel which is outside of Criminal Procedural Code such as Law Number 11 Year 2008 about Information and Electronic Transaction Law. This reunitingis important to make criminalization and penalization which are in sectoral law outside of Criminal Procedural Code can be synchronized by Criminal Procedural Code and reality which happens in court of law in Indonesia.

If we see criminalization philosophy is there is law fundamental of ultimum remedium, which means that criminalization should be last effort in law enforcement. As the result, it is suggested a case can be resolved through other way such as penal mediation, Restorative Justice approach that try to resolve peace with the result it does not required law.

\section{REFERENCES}

Books

Arief B. Nawawi, Kapita Selekta Hukum Pidana, cetakan ke-3, Bandung, PT. Citra Aditya Bakti, 2013

Adji Oemar Seno, Perkembangan Delik Pers di Indonesia, Erlangga, Jakarta, 1990

Casey Eoghan, Digital Evidence and Computer Crime: Forensic Scince, Computers, and the Internet: Third Edition, Maryland, Elsevier, 2011.

Hamzah Andi, Hukum Acara Pidana dalam Teori dan Praktek, Ghalia Indonesia, Jakarta, 2004.

Mansyur. M. Arif. Dididk, CYBER LAW Aspek Hukum Teknologi Informasi, PT. Refika Aditama, Bandung, 2005.

Reinhard Golose Petrus, Seputar Kejahatan Hacking: Teori dan Studi Kasus, Dharmaputra, Jakarta, 2008.

Sitompul Asri, Hukum Internet Pengenalan Mengenai Masalah Hukum Cyber Space, Citra Adiyta Bakti, Bandung, 2001.

Suhariyanto Budi, Tindak Pidana Teknologi Informasi (Cybercrime) Urgensi Pengaturan dan Celah Hukumnya, PT. Rajagrafindo Persada, Jakarta, 2013.

Widodo, Sistem Pemidanaan dalam Cyber Crime, Yogyakarta, Laksbang Mediatama, 2009. 


\section{Web/Article}

https://issuu.com/tifafoundation/docs/menggugat_pasal-

pasal_pencemaran_nama_baik/ 32 diakses pada tanggal 26 Juli 2017 pukul 12.18 Wita

Reydi Vridell Awawangi, 2014, Pencemaran Nama Baik dalam KUHP dan Menurut UU No. 11 Tahun 2008 tentang Informasi dan Transaksi Elektronik, Lex Crimen Vol. III/No. 4/ Ags-Nov/2014, 